\title{
Quest for quality and relevant higher education, training and learning in Kenya: an overview
}

\author{
Wycliffe Wanzala \\ Department of Biological Sciences, School of Pure and Applied Sciences, South Eastern Kenya University, P.O. Box 170-90200, Kitui, \\ Kenya \\ Department of Natural Sciences, Faculty of Science, The Catholic University of Eastern Africa, P.O. Box 62157-00200, Nairobi, Kenya
}

Email address:

osundwa1@yahoo.com (W. Wanzala)

To cite this article:

Wanzala Wycliffe. Quest for Quality and Relevant Higher Education, Training and Learning in Kenya: an Overview, Education Journal. Vol. 2, No. 2, 2013, pp. 36-49. doi: 10.11648/j.edu.20130202.13

\begin{abstract}
Kenya is in the midst of many transformations and transition processes of its institutions and administrative/governance structures following the promulgation of a new constitution on 27th August, 2010. Institutions for higher education, training and learning top the list of priority institutions targeted for these revolutions and evolutionary processes. The institutions are expanding at an alarming rate and are greatly challenged with the delivery of quality and relevant education, training and learning compounded with political interference, corruption, nepotism and socio-economic mayhem under the watchdog of weak national agencies charged with the responsibilities of standardization of an existing educational system together with its quality and relevance to the society it is serving. Conversely, it's regrettable that irrelevant and poor quality education and training is being offered in these institutions while hiding under "ISO certification", the International Organization for Standardization of systems/institutions and under the watchdog of the Commission for University Education (CUE) and standardization and quality assurance units in the ministries of Higher Education, Science and Technology and Education. It is imperative to note that it took the Kenyan Government about 45 years to build 7 public universities, which are currently not yet fully equipped to anticipated international standards and notwithstanding, the same government takes only 5 years to build 23 more public universities in a fragile economy. This marks a more than $200 \%$ growth in the number of public universities in Kenya. In addition to this and over 227 existing tertiary institutions, the Government is expected to set up at least a public university in each of the 47 counties according to Universities Act, 2012; implying that more institutions for higher education, training and learning are in the offing should any of the 47 counties be found without a university once the devolved system of governance starts operating as from Tuesday April 9th, 2013, following the swearing in of the 4th President of Kenya, and henceforth, change of country's leadership. Will the existing Kenyan political system and socio-economic status sustain this university growth rate and produce and maintain quality, relevant and internationally competitive graduates? Whether the answer is "yes" or "no", it's only hoped that the on-going legal, economic, structural, political, governance and regulatory reforms in key stakeholder institutions and watchdog agencies will successfully take root and ensure delivery of quality and relevant education, training and learning in Kenya, thereby consenting to its provisions and intended purpose in the society.
\end{abstract}

Keywords: Higher education and training, Quality and relevant education, Standardization of educational systems, Educational reforms and development, Expansion of higher education

\section{Introduction}

Education as a complex system rooted in the society's political, socio-cultural and economic context, is primarily key to preparing the much needed workforce with proficiency, competences and techniques required to develop and transform global economies of states and governments (UNICEF, 2005; Khan, 2007; Ojiambo, 2009; Kipkebut, 2010). The education system is therefore supposed to evolve in tandem with the dynamic needs and demands of the society it serves while the drivers of the evolution and revolution processes putting into considerations the factors of access, equity, quality, affordability and relevance in 
order that it sustainably meets the aspirations of the existing economy and industry (Ojiambo, 2009). Critical to sustainable socio-economic development in our society today is the quality and relevance of education and training at all levels and long-life learning professional courses offered to the young generation that comprises tomorrow's human resources for development-based leadership (Kinyanjui, 2007; Kipkebut, 2010; Mogambi, 2013). Nonetheless, the quality of education and training has previously received a lot of considerations in Kenya with the establishment of the National Assessment Centre (NAC) to monitor learning achievements however, with a special focus on only primary and secondary education, unfortunately (Wanjohi, 2011). While on the other hand, little attention was focused on the university education whose demand has tremendously increased in Kenya as more school-leavers and nonuniversity graduates in labour force hurry for university education, training and learning to boost their chances in the labour market (Ojiambo, 2009; Fortunate, 2013).

In Kenya, education, training and learning systems are historically among the most important sectors of the government's concern, accounting for almost $30 \%$ of total government expenditure and $6.2 \%$ of the country's GDP in 2007/08 (Ngolovoi, 2009). Notwithstanding the expansion of the higher education, training and learning systems in the past 50 years, the capacity of these sectors in Kenya is still limited and only $3-4.2 \%$ of the university-aged cohort are enrolled in university education, training and learning systems (Ngolovoi, 2009). It is expected that students seeking university education, training and learning by 2015 will range between 160,000 and 180,000 , thereby increasing the proportion of those accessing university education, training and learning from $4.2 \%$ in 2005 cohort to $15 \%$ by 2020 (Kinyanjui, 2007). Whether or not the anticipated number of students will sustainably be managed in the higher institutions and bear a resemblance to the rest of the world in attaining the required standard of university education, training and learning, is yet to be explicitly determined under the prevailing socio-economic conditions.

Studies show that the quality of education, training and learning a student receives is due to a multiplicity of factors starting with the quality of the lecturers followed by training facilities, state of students, processes through which professionally trained lecturers use learner-centred teaching approaches, knowledge content, holistic learning environment and outcomes that include knowledge, skills and attitudes (UNICEF, 2000; The Centre for Public Education, 2005; Wilson, 2009). Yet, teaching profession is indeed very complex and challenging; meeting the needs of these challenges is just a nightmare, particularly in an environment with limited resources like in Kenya, a fact, unfortunately, denied by a considerable number of leading administrators and managers in institutions of higher education, training and learning. The challenges demand a broad knowledge-base of the subject matter, curriculum, skills, techniques and standards; a process that needs an elaborate and effective mentoring system of the lecturers following their reception of quality and relevant education and training. The situation further demands that an effective and competent lecturer should have some considerable teaching experience, professional certification, overall academic ability, enthusiasm, a motherly-caring attitude, a love for education, training, learning and acquiring knowledge, knowledge of discipline and classroom management techniques, skills and a desire to make a difference in the lives of young people. However, the quality of teaching and training is not simply determined by an individual's knowledge or ability, but also by the contexts in which lecturers work (The Centre for Public Education, 2005; Wilson, 2009). Convalescing education quality thus necessitates holistic policies with reference to recruitment processes, maintenance mechanisms, working conditions as well as professional development and welfare of students. As much as these facts are fully recognized and comprehensively legalized to some extend (Kinyanjui, 2007), they are only theoretically realized and practically ignored for unknown reasons and/or for personal interests by those charged with the responsibilities. When all's said and done, quality control and assurance remains one of the most critical issue in the revolutionary history of higher education, training and learning albeit the existence of regulatory agencies to control and provide the framework upon which the expansion of institutions for higher education, training and learning should be based.

By ushering in new leadership and governance, which may define a new path and dawn in the evolutionary history of Kenya, the country thrash about to improve an underfunded and botched sub-sector of higher education, training and learning with on-going legal and regulatory reforms promising sustainable changes in overall structure, knowledge delivery and curriculum design and development. This manuscript discusses the current state of quality and relevance of higher education, training and learning in Kenya while also focusing on the challenges facing the education, training and learning systems and examining some responses to these challenges.

\section{Institutions for Higher Education, Training and Learning in Kenya}

Since independence, there has been an increasing demand for higher education, training and learning due to job market requirements and increasing population, hence, the spontaneous development of institutions for higher education, training and learning (Kipkebut, 2010). These institutions include all formal and non-formal education, training and learning offered after the basic education, training and learning cycle and comprises middle level institutions and university levels of education, training and learning. Under this category are found all: - (i) teacher training colleges, (ii) trade, technical and vocational institutions, (iii) sectoral 
colleges within government ministries, (iv) institutions offering pre-university academic programmes, (v) private and public chartered universities, and (vi) non governmental institutions offering commercial and other skill- based development courses beyond basic education, training and learning and approved by the Commission for University Education (CUE), an institution that is charged with the responsibilities of establishing universities and their standardization, accreditation, governance and supervision. The institutions offer certificates, ordinary diplomas, higher national diplomas, post-graduate diplomas, bachelor degrees, masters' degrees, Doctor of Philosophy degrees, Degree of Doctor of Education, Doctor of Science and Honorary degrees etc. In terms of numbers, these institutions include:- 22 public universities, 8 public university constituent colleges, 15 chartered private universities, 6 chartered private university colleges, 13 universities with letters of interim authority (LIA), 2 registered private universities preparing for the award of LIA, over 40 public technical/vocational/trade schools/colleges and over 187 private technical/vocational/trade schools/colleges. In addition, the Government is expected to set up at least a public university in each of the 47 counties according to Universities Act, 2012; implying that more institutions for higher education, training and learning are in the offing should any of the 47 counties be found without a university once the devolved system of governance starts operating. Into the bargain, and in pursuant with the provisions of Universities Act, 2012, there are over 22 post-secondary school institutions, which have been granted authority by CUE to collaborate with local and/or international universities/institutions for higher education, training and learning to offer diploma and degree programmes. In September, 2010, the Ministry of Higher Education, Science and Technology listed 592 postsecondary school institutions operating countrywide without registration, and hence, not accredited by CUE (Nganga, 2010b). While in January 2011, the Ministry of Higher Education, Science and Technology published a list of 110 post secondary school institutions countrywide to be closed down because of operating without registration with the ministry and accreditation from CUE (Lime et al., 2011). Further it was noted that CUE had only accredited 61 out of 350 colleges operating countrywide (Anon. 2012). Most surprisingly, it is estimated that there are about 83 tertiary institutions, which are collaborating with local and/or international universities to offer degree programmes without accreditation from CUE (Ngure, 2012). In an attempt to respond to this kind of malpractices, CUE has in the past three years, intensified the crackdown on such institutions operating illegally, an operation that has witnessed, Busoga and Bugema Campuses of mother universities in Uganda, purportedly collaborating with Tracom and Elgon View Colleges in Kenya, respectively, close down in January 2011. Other tertiary institutions, over a 100 of them, were announced to be closed down in Eldoret and Kitale towns (Ndanyi, 2010). Despite such efforts by CUE, counterfeit education, training and learning institutions continue to emerge; the case of Dreamline College in Nairobi, Kenya, the Campus of Kampala International University in Uganda (Anon., 2012). Unfortunately, such efforts with a view to taming bogus and mushrooming education, training and learning institutions are not maintained and spread uniformly across the country, particularly in remote and much localized village towns where it is not easy to identify such malpractices. This rate of development and expansion of education in institutions for higher education, training and learning necessitates the need to develop strong institutions to help regulate, co-ordinate and assure quality and relevance of education, training and learning that is tandem with and responsive to the needs of the society.

\section{Basis for Establishing Institutions for Higher Education, Training and Learning in Kenya}

The education system in Kenya, following the establishment of few institutions before, during and the early days of post colonial era, was meant just to provide the basics in life to ease communication between the colonial masters and Africans who provided the much needed labour force (Mwangi, 2012). Furthermore, university education was a reserve for only a few privileged students who academically excelled (Wachira, 2013) and at the independence time, this type of education could only be accessed abroad through competitively limited western-based scholarships. Since independence time, major transitions and reforms in Kenyan education system were made and focused on its access, equity, quality, affordability and relevance (Wanjohi, 2011; Ministry of Education, 2012) and tremendously expanded institutions at all levels to meet the aspirations of rapidly growing Kenyan population.

As part of socio-economic pillar, the need for skilled labour force, which requires advanced training at degree level, was realized and necessitated the development and expansion of university education. This was however, further reinforced by the increasing Kenyan population and due to the fact that it was also recognized as an essential ingredient in achieving the country's vision 2030, the main national flagship project for socio-economic development agenda. Nevertheless, the political fraternity took advantage of this opportunity to claim and initiate ethnic- and regional-based university campuses and colleges for gaining political supremacy and mileage. To consent to this idea, the same political leadership was quick to influence the decision of appointing the institutions' Chief Executive Officers (CEOs) and managers who are therefore expected to provide an academic leadership that pleases their "god fathers". This state of affairs was due to the claim that as regional and ethnic political leaders, were rightfully placed in the process of ensuring that the needs of the newly created devolved governance system in the newly promul- 
gated Kenyan constitution were adequately met at a County levels. This political manoeuvre and behaviour once allowed in education system, waters down the quality of education, training and learning and hence, that of graduates.

The decision to establish and develop some institutions for higher education, training and learning was influenced by donor agencies due to their own vested interests, which may not have necessarily been tandem with the government's national development agenda. This continued postcolonialism influence and interference, therefore, is also to blame for the poor quality education, training and learning provided in the country because, at times, the donor agencies withdraw funding before the institutions are fully developed and become self-sustaining.

On the other hand, the private sector considered the issue of the development and expansion of institutions for higher education, training and learning in Kenya (particularly university education) as a stature and business enterprise that could help earn fame, a living and foster the framework upon which the much needed skilled labour force anticipated to be deployed in the newly created devolved governance system could be developed, produced and achieved (Mwangi, 2012; Mogambi, 2013). In some cases, this state of affairs provided for business competition in institutions for higher education, training and learning, the result of which has been to compromise quality and result into mushrooming village university campuses and colleges, which do not meet the standards of a university education, training and learning in any ways other than increasing the number of irrelevant graduates on the job market (Fortunate, 2013).

It is therefore self evident that institutions of higher education, training and learning are established based on a myriad of reasons, some of which are not clearly understood and defined in normal professional circumstances, but somehow concealed under the existing legal framework in the government. Nevertheless, it is imperative to note that the opinion to establish a number of institutions of higher education, training and learning is, in most cases, politically instigated instead of being based on the existing need necessitated by the increasing population looking forward to train at higher levels and the demand of highly skilled labour force on the job market. Therefore, institutions such as these ones founded on political grounds may have little to do with quality education, training and learning as the primary goal of the planners, initiators and management team is to achieve political supremacy and mileage out of the institutions regardless of their state. This is indeed a socio-economic problem to reckon with in the society and owes much to the country's sneaky political system, which unfortunately has enslaved and convinced citizens to trust its leadership as the golden truth from the Bible as is out to give pleasure to the majority with its sweet words on platforms during political rallies/campaigns, manifestoes and self-seducing education policy documents on shelves in various ministries without eminent focus on their practical implementation and sustainable management strategies. This has however entertained the development and fruition of very weak structures and watchdog agencies of standards and quality in education, training and learning sectors, whose main aim, unfortunately, has been to meet the aspirations of the appointing authority, donor agencies and that of the western world, instead of the citizens they purport to serve.

\section{State of Institutions for Higher Edu- cation, Training and Learning in Kenya}

In the Kenyan society, the quality and relevance of education, training and learning systems are currently viewed as endangered resources for socio-economic and -cultural development. Fears have crept every key stakeholder in education, training and learning systems for realizing this state of affairs but getting a sustainable and eminent solution to this crisis appears not forthcoming soon, hence the continuity of the "status quo". As a matter of fact, in both private and public institutions for higher education, training and learning in Kenya, there is a common consensus that quality is low, academic fraud is rampant, efficiency is weak, relevance is questionable and wastage is noticeably significant. After a long period of time of national and international endeavours to deal with the challenges facing education, training and learning systems, particularly following the commitments made to reach the goal of Education for All by 2015 at Chom Tian (Jomtien) in Thailand in 1990 and its reconfirmation in 2000 at the World Education Forum in Dakar, Senegal during the agreement on the $D a$ kar Framework for Action on Education for All, we are still falling short of targets by far (Hallak and Poisson, 2007). The meeting in Dakar confirmed that lack of political will and commitment, weak governance, poor transparency, inadequate accountability and corruption (particularly unbecoming behaviours in procurement procedures in institutions for higher education, training and learning) are, among others, the key problems of education, training and learning systems in developing countries in particular.

Although institutions for higher education, training and learning in Kenya produce a considerable proportion of labour force at national, regional and international levels, the poor ranking of these institutions (particularly universities), probably can help explain and communicate their poor state (Tairo, 2006). Universities, which are considered to be centres of excellence in education, training and tlearning, knowledge generation and intellectual and socioeconomic and -cultural development in the society, are unfortunately not serving these anticipated purposes in Kenya. The poor situation of teaching staff compounded with their low payments, does not allow them to get committed to providing quality performance in the institutions. Crude methods of teaching that lecturers use in resource limited environments negatively impacts students, thus compro- 
mising the quality of graduates. The examination system has come into poor reputation of irregularities through:tribalism, nepotism, cheating, plagiarism, university administration favouring students in case of examination irregularities, marks being exchanged for sex, students corrupting registrar officials to print for them transcripts and degree certificates with desired grades etc. Additionally, poor response to technological advances, poor administration, poor student welfare services and frequent student unrest, have significantly contributed to poor quality education, training and learning in higher institutions.

There are many indicators for this poor quality state of higher education in Kenya, namely:- poor learning environments (some with a lot of noise from bars and bus stops), disproportionate student/staff ratio, high rate of conversion of middle-level colleges to universities, poor salaries of employees manifested in frequent industrial strikes and mass action, flawed admission processes, charging unbelievably low fees and shortening semesters to save on monetary resources and attract large numbers of students, a deliberately high pass rate for students to attract them, awarding of academic honorary doctorates to potential donors and business partners to lure them into donating funds for development projects, students conducting illicit businesses in their halls of residence/hostels, sharing of poor training facilities and crowded lecture rooms (largely manifested in the practically-oriented courses being theoretically taught), extremely poor and dilapidated infrastructure, considerably high proportions of undisciplined students in universities, campuses and colleges, frequent national catastrophes affecting the state of learners, professionally poor quality lecturers (including poor hiring and promotional procedures of substandard personnels), moonlighting and brain drain amongst lecturers, heavy teaching workloads and forceful allocation of courses outside lecturers' professional training of which one either accepts or be dismissed, mass education and generalized unemployment, poor processing systems of examinations and results, with loopholes for manipulations at the advantage of the students, inexperienced university administrators and managers who develop and formulate poor university policies, which undermine quality education, training and learning; a fact denied by the country's watchdog agencies for education standards and quality such as the Commission for University Education, the newly established Education Standards and Quality Assurance Commission and the National Qualification Framework Agency in the ministries of Higher Education, Science and Technology and Education, respectively (CHE and AfriQAN, 2012; Mogambi, 2013; Fortunate, 2013). In Kenya, the Commission for University Education is a regulatory agency charged with the responsibilities of planning, advising, accreditation, establishment, governance, management and quality assurance in higher education system. The commission ensures quality assurance mechanisms, complemented by the Directorate of Quality Assurance and Standards, which is the Kenyan professional arm of Ministry of Education.

This is further convoluted by the fact that on many occa- sions, lecturers are no longer rated based on the quality professional training, experience, moral values and integrity, quality of research and publication output but depending on the number of students that one is teaching (translated into monetary values one controls and earns the institution in question), political power behind one's employment and how well one is connected to the institution's main administrators and managers. Additionally, in Kenyan institutions for higher education, training and learning, one's level of sycophancy and bootlicking speak for themselves and are directly proportional to one's employment, status in the institution and henceforth consideration for promotion through academic ranks. The complication of this issue became worse when promotion into academic positions and/or moving through academic ranks in a number of institutions for higher education, training and learning started being pegged on : - 1), women affirmative action, 2), gender balance, 3), country minority and majority balance, 4), tribal balance, 5), regional balance, and 6), representation of persons with disabilities. This has contributed significantly in watering down the quality of academic staff in institutions for higher education, training and learning.

\section{Programmes in Institutions for High- er Education, Training and Learning in Kenya}

In Kenya, institutions for higher education, training and learning have tremendously evolved over the past 50 years to offer diversified academic programmes. Each one of the programmes has both merits and demerits and is unique to a given category of target learners for which it is formulated to serve.

\subsection{Distance, Adult and Continuing Education Pro- gramme}

This is one of the oldest academic programmes in institutions for higher learning in Kenya and is philosophically known as "taking education at the doorsteps of the learners". Its origin is traced back in 1953 at Makerere College in Uganda before it was transferred to then University College, Nairobi in Kenya in 1963 and further developed into an institute of Adult studies in 1966 (Anon., 2013). The programme was designed to help those students who may not be nearby to take courses either on full time or part time (evenings and weekends) basis. Varied entry qualifications are considered depending on the level of the course the applicant wishes to study ranging from certificates, diplomas, bachelor degrees, masters' degrees to doctorate level. The programme targets persons of different categories including but not limited to: - (i), school leavers who wish to pursue their education totally or partially through distance mode, (ii), employed and self-employed persons who would like to further their education for careers' opportunity or self-fulfilment, and (iii), any other person in- 
terested in further education and life-long learning education (Information Brochure, 2010/2011). Education and training is offered through distance learning modes involving :- well designed and written self-instructional print study modules, e-learning materials, audio-video cassette support for the printed modules, computer and satellite mediated strategies especially in the management and science programmes interfaced with limited face-to-face interactive sessions at Extra-Mural Study Centres throughout the country. Additional learning facilities and resources are accessed from other similar institutions through collaborative arrangements with one's own institution. However, on many occasions, facilities and resources to support this programme are always limited in time and space.

\subsection{Regular Programmes (Module I Programmes)}

This is a standardized programme in all its operations in Kenyan public and private universities. It mainly involves the yearly admission of Kenya government-sponsored students from secondary schools having sat for Kenya Certificate of Secondary Education (KCSE) and passed with minimum university entry and KCSE subject cluster requirements by the University Senate through the Public Universities Joint Admissions Board (JAB) ${ }^{*}$. Each applicant should be able to meet the minimum university enrolment requirements for a particular university training academic programme of interest and this entirely depends on the performance of its KCSE subject cluster, which specifically defines the academic programme of interest. Students under this particular academic programme normally apply for loans, grants, scholarships and bursaries from HELB to support them throughout the period of their study as it deems fit (Otieno, 2004).

This was the initial traditional academic programme of education, training and learning in higher institutions that was involving face-to-face teaching throughout the training sessions and which is now associated with regular programme, the second most popular programme. However, this programme proved to be just too expensive for the government to maintain and sustainably manage it through generations (The Standard Group Limited, 2009).

Further, the regular programme was claimed not to meet the aspirations of a considerable proportion of the university aged cohort in the country and beyond; and further, the programme was not in line with the requirements of the recommendations made by The Public University Inspection Board to increase students' intake as students were admitted in the programme according to the available accommodation facilities instead of the existing training and learning resources and facilities (Kinyanjui, 2007). This

\footnotetext{
${ }^{*}$ This is an inter-university, non-statutory body (whose membership comprises Vice Chancellors, Deputy Vice Chancellors, Principals of Colleges, Deans of Faculties/Schools, Directors of Institutes/Schools and academic registrars of public universities and representatives from the Ministries of Higher Education, Science \& Technology and Education) that selects students who join public universities under government subsidy.
}

limited a considerable proportion of potential students to locally pursue university education, training and learning and resulted into the famous "African continent brain drain", as those who are seeking similar university education, training and learning abroad are reluctant to come back upon completion of their studies. This therefore, necessitated the need to develop alternative academic programmes, which are similar to those sought after abroad and are in tandem with the changing needs and aspirations of the target population in the Kenyan society. On the other hand, the regular programme still remains the most sustainable, effective and efficient programme for university education, training and learning, particularly in practicallyoriented science- and technological-based courses such as agriculture, biomedical sciences, nuclear physics, physical planning, engineering, architecture, medicine and surgery, pharmacy, dental surgery, nursing, biochemistry, meteorology, physics, biology, chemistry etc.

\subsection{Self-Sponsorship Programmes (Module II Pro- grammes)*}

Module II students gain entry to universities on the basis of different criteria that vary from university to university and not nationally standardized, thereby watering down the quality of students for university education, training and learning. Admission into the programme is through the universities' admissions committees located in Schools, Institutes or Departments of various institutions for higher education, training and learning. Admission is based on the set minimum requirements for each academic programme by a given university in question. In Kenyan public Universities and other institutions for higher education, training and learning, the Module II programmes started in 1998 at the University of Nairobi (UoN) to open up university education, training and learning opportunities to qualified Kenya Certificate of Secondary Education (KCSE) graduates who could not be admitted through JAB, but later was skillfully packaged to be an important cash cow. The programme has ever since evolved to be the most popular programmes being described by different terminologies depending on the institutions and nature of study viz; parallel programs, evening programmes, weekend programmes, part-time programmes, self-sponsored programmes, schoolbased programmes, school-focused programmes, direct entry programmes, full-fee-paying academic programmes etc. (Wainaina, 2011). Throughout the current discussion,

\footnotetext{
*While very modest tuition fees were introduced in public universities in Kenya in 1991 for students in Module I programmes, the generated resources were insufficient given the severely limited number of students. Therefore, a dual track tuition policy was introduced in 1998 via the self-sponsored, or Module II programmes. Dual track tuition policies are characterized by a highly restricted, "merit-based" entry to free or, as in the case of Kenya, very low cost higher education, with other applicants not so admitted permitted entry on a feepaying basis. In Kenya, the module I students pay tuition fees of KSh. 16,000 (US\$542), while the module II students pay about KSh. 150,000 (US\$5,081) and considerably more in some disciplines such as medicine.
} 
Module II programmes may be considered to refer to the entire full- fee- paying /privately spon sored /adult/ continuing/ lifelong education programmes in institutions for higher education, training and learning in Kenya, which are being offered to students who are not selected through JAB, (Wainaina, 2011). Under these programmes, students pay the full cost of the course unlike their regular counterparts who are subsidized by the Government. Further, the students fend for themselves and pay for their own accommodation. With Module II programme, students who would previously have had their chances of advancement curtailed now have a chance to pursue their degree choices depending on his/her economic status. Four years ago (i.e. March, 2009) the Public Universities Inspection Board recommended the merging of Regular and Module II programmes in Kenyan public universities but following the evaluation of the recommendation by the key stakeholders (ViceChancellors Committee, Commission for University Education (CUE) and Higher Education Loans Board (HELB) chief executives and Higher Education Assistant minister, Dr. Kilemi Mwiria), it became practically impossible to implement the recommendation and the programmes continued to date (The Standard Group Limited, 2009). Nevertheless, these programmes are regarded to be for the rich in the society and as short-cut programmes for one to get a degree so easily as they lack essential ingredients for quality assurance and standardization as regular programmes. At its initial stages, many regular students accused the university administration of favoritism and nepotism with Module II programme, which was argued that students in the programme did a much easier examination and got extra help since they were the ones that had the money the institutions needed most. It was further argued that the Module II programme focused so much on money that it would encourage high school students to become lazy as the students would buy their way into universities with their money, thus watering down the quality of graduates. Although all these allegations have not been investigated and addressed, it is not a surprise that today, the number of parallel students in most of the public universities now surpasses that of the regular students.

\subsection{The African Virtual University programme}

This is perhaps the most recent and probably the fast expanding programme in institutions for higher education. Kenya has tremendously embraced virtual initiatives in post-secondary education institutions such as University of Nairobi, Egerton University, Moi University, Maseno University, Kenyatta University and Alma Training Institute, Mombasa.

The African Virtual University (AVU), which has its headquarters in Nairobi, Kenya, is an intergovernmental network organization that was started in 1997 with a view to promoting and supporting initiatives in open, distance and electronic learning (ODEL) in institutions of higher education, training and learning in Africa. The ODEL has greatly increased access to higher education in many parts of Africa in an affordable, cost-effective, flexible and sustainable manner by allowing universities to use e-learning portal to collaborate in content development and delivery practices and further promote group interaction, institutional interaction and self-learning (Muhirwa, 2009). Given that AVU's architecture is designed to use mixed models of delivery such as video conferencing, use of the internet, CD-Rom and cassettes and print-based materials and mobile learning, this kind of education, training and learning is heavily weighed down by poor quality of synchronous online communication, frequent electric power failures and its unavailability in remote areas, lack of locally trained quality tutors and lecturers, inadequate e-learning facilities and resources and unavailability of funds for investment. Notwithstanding this realization of many shortcomings, many African students continue to train and graduate from this AVU programme before addressing these challenges.

\section{Use of Information and Communica- tion Technologies (ICTs) in Education, Training and Learning processes}

As the Kenyan population providing labour force increased in size, structure, diversity and complexity, its educational provision to improve skills, competences and proficiency demanded that knowledge delivery must extend beyond the habit of continuous contact with the instructor from enrolment time of anyone given course up to the time a candidate sits for a final examination (Khan, 2007). This kind of training arrangements has included programmes such as open and distance learning (also called continuing education and school-focused by different institutions) and the so-called parallel, involving non-formal instructions and training programmes. Although at times parallel programme is more or less similar to regular programme, it is more flexible and student-centred to fit the study time and the financial status and henceforth allowing sustainable educational arrangements to be made by the learner. These programmes are nevertheless foreign, thus originating from the west and implemented in Kenyan institutions without considerations of the quality of lecturers handling the programmes, training materials and facilities, delivery methods, underlying mechanisms of their operations etc. This has in turn, adversely affected the quality of learners graduating from these programmes, thereby churning out semi-literate graduates, a fact denied by institution chiefs and managers. A considerable proportion of institutions have focused on encouraging, applying, synchronizing and smoothing the progress of the use of information and communication technologies (ICTs) to enhance teaching, training and student learning capabilities, particularly in satellite campuses and colleges. Although institutions are currently busy integrating satellites and ICTs into educational systems to deliver distance education, they have not had sig- 
nificant impact on improving quality training of remote learners who, unfortunately, are increasingly becoming the majority. As much as open and distance learning programme is increasingly becoming well adapted to life-long learning, training and professional advancement outside the traditionally known schooling environment involving faceto-face teaching, there is indeed great need to improve the sector first. For open and distance learning programme to be successful and useful to the target population, it requires the institutions involved to ensure: - 1), the development of a comprehensive induction programme of the instructors/lecturers involved, 2), effective and efficient ICT facilities and resources for teaching during the short period of time the learners are in contact with the instructors/lecturers, 3), the development of detailed, well updated and self-training modules for the learners by the inducted instructors/lecturers, 4), instructors/lecturers remain in contact with the learners while away from the campuses through a well developed network system of ICTs accessible by learners at their respective locations, 5), the development of a credible, efficient and effective admission procedure that does not allow substandard learners into the system, 6), a unique examination and evaluation system, which takes into account, the nature of the programme, students and learning environment and 7), the development of a unique but a credible, efficient and effective monitoring and evaluation secretariat to ensure access, equity, quality, affordability and relevance of the programme. This therefore requires a heavy investment (in terms of human, monetary, e-learning and physical resources) by the institutions before mounting a credible, efficient and effective open and distance learning programme involving ICT (Katitia, 2012). For many institutions for higher education, training and learning in Kenya, these funds are not available and forthcoming soon for this heavy investment and yet the programmes are running with a very high number of students enrolled and who are constantly graduating every other year from these implausible programmes.

\section{Challenges Facing Higher Education, Training and Learning in Kenya and some Responses}

As a country, access, equity, quality, affordability and relevance of education and training system have remained fundamental challenges to consider in the design and implementation of education and training systems (Kinyanjui, 2007; Mwangi, 2012; Ministry of Education, 2012). Even though over the years, the Government of Kenya has enthusiastically expanded access and equity to education, training and learning, there is vast evidence of shortcomings such as anticipated increased numbers of students, management of quality education, staff and university life, university governance, management, funding and accountability, how the private institutions can be supported by government on equal footing as public universities, development of new university academic programmes and their delivery mechanisms, mechanisms for transfer of academic credit across institutions of higher learning, regulation of the establishment and management of university campuses for both public and private universities, education policies and reforms, linkage of university education and industry and global/national socio-economic development agenda and position Kenya as an education destination for students from the region and the world (Kinyanjui, 2007; Mwangi, 2012; Wachira, 2013). Whether or not the on-going legal and regulatory reforms on university education will be able to address all these challenges and ensure deliverance of quality and relevant university education, training and learning remains a mystery under the prevailing conditions of the Kenya's unpredictable socio-economy compounded with drastic changes of the country's political leadership and governance structures.

Although the Kenya government is faced with all these challenges in its university education, it has increased its funding to public universities from 259 million US dollars to 287 million US dollars in the financial year, 2011/2012 (Mengo, 2011). Further, the government is scheduled to spend US\$56 million of donor funding to help improve vocational and technical education countrywide to meet the demands for skills base in labour market and at the same time replacing the institutions previously upgraded to become universities (Nganga, 2010a). There have been some attempts to respond to these challenges as it was previously witnessed by His Excellency Hon. President Emilio Mwai Kibaki planning to open 15 new public universities within 2 months to ease pressure on the limited education facilities and resources in the existing 7 universities. The practicability and henceforth sustainability of this idea however appeared repugnant and was received with mixed feelings amongst the academicians and educationists across the nation. The opponents together with the critics on face books and twitter were opposed to the idea of president awarding charters to constituent university colleges at this rate as it was argued out that most of these institutions being promoted do not merit university status as they lacked some very basic facilities such as libraries, lecturers, teaching laboratories, lecture theatres, pre-requisite infrastructure etc, and therefore the institutions cannot offer quality education and training and produce competitive graduates. Nevertheless, what initially appeared impossible in the eyes of the majority has become implemented as the Kenyan President has granted charter to all the fifteen tertiary institutions, which were initially promoted to become university constituent colleges to now assume full status of a university and operate independently. On the other hand, the President who is retiring in a fortnight and is out to leave behind legacy, was quick to defend this move that the creation of new universities was being done under the Universities Act, 2012, which opens a new chapter in the history of higher and tertiary education, training and learning in Kenya as 
the Act provided a tough environment for accreditation and quality assurance of university education, training and learning (Anami, 2013). Whether or not the opponents of the president are correct, time will tell and disapprove or approve!

Also, there has been an increased funding of over 900 research and innovation projects and training of postgraduate (MPhil/MLL/MA/MSc/MBA and PhD) students in public universities by the defunct National Council for Science and Technology (NCST), a statutory institution of the government of Kenya, established in July 1977 by the Science and Technology Act. Cap. 250 of the Laws of Kenya. While on the other hand, Higher Education Loans Board (HELB)* established by an Act of Kenyan Parliament in 1995 (Cap. 213A) has tremendously increased its loans, grants, bursaries and scholarships to all Kenyan students (both undergraduate and postgraduate) in both public and private institutions of higher education, training and learning. In consequence of the rapidly rising demand for financial support from HELB, the Board has partnered with Commercial Bank of Africa, Kenya Commercial Bank, the Co-operative Bank of Kenya Limited, Equity Bank Limited and National Bank of Kenya Limited, to provide alternative financing for students who may not succeed in getting direct financial support from HELB. Other alternative funding mechanisms of education and training include: - application of bursaries and grants from Constituent Development Fund (CDF), which was established by an Act of Parliament in 2003 to finance community-based programmes with a view to alleviating poverty (Ngolovoi, 2006; GoK, 2006). On other hand, the private sector (private universities and banking institutions) organizes financial aid to a limited number of students (Otieno, 2009).

Additionally, NCST has established a kitty for incentives for scientific publications for personnels in research institutions and universities to increase their contribution to generating global knowledge by disseminating their research findings through publications. All these initiatives may be very important as recommended by the Public University Inspection Board in meeting the demands for teaching staff in both public and private universities and help improve quality (Kinyanjui, 2007), only if well nurtured.

There are also calls by CUE for co-operation and collaboration of state-owned institutions/universities, staff, students, private sector, professional bodies, local communi-

\footnotetext{
*It should be noted that a student loan program (the Higher Education Loans Fund) existed even before independence. The Fund was shelved upon independence and re-introduced in 1974. However, it remained more or less a grants scheme, as no effort was made to recover the loans. The program was reformed and successfully re-introduced for the third time in 1995 as the Higher Education Loans Board (HELB) (Otieno, 2009). This happened when there was a shortfall in the public budget for higher education, a scenario that brought about the impetus for institutions to look for alternative income generating sources, in effect, reducing their overdependence on the government budget (Kiamba, 2004). This in turn gave birth to Module II programmes in1998 and other income-generating activities in many public institutions for higher education, training and learning (Kigotho, 2000).
}

ties, civil society and development agencies/industry in the development of high quality academic and training programmes, which are responsive to the needs and demands of the society. In the offing, is a national policy on Open and Distance Learning programme to particularly open up education to many working and middle class persons who did not get chance of entering the few elitist institutions of higher learning of the time. To further address this issue, The Open University of Kenya (OUK) was established by a technical task force set up in the ministry of Higher Education, Science and Technology to provide an institution with sustainable framework and structures for comprehensively and successfully offering online learning and training thus reducing congestion in universities and meeting the aspirations of the target population on the job market.

\section{Understanding Quality Education, Training and Learning under the Kenyan situation}

Quality and relevant education, training and learning are amorphously nonspecific statements whose definition allows for its understanding as a complex system rooted in a political, cultural and socio-economic context of evolution of society's development agenda (UNICEF, 2000). It comprises an assortment of components detailing: - 1, strategic planning of education and training (regulation of degrees and studies, curriculum design and sustainable management of institution resources), 2, development and implementation of strategic plan (that supports teaching and learning in institutions and academic guidance and advice by professionals), 3, monitoring and evaluation of the strategic plan on education and training (objectively by internal and external mechanisms) 4, follow-up and development measures of the strategic plan (through institution projects and services, operating management systems, briefing workshops and seminars as an update strategic mechanism on the development of teaching and training), and 5, national and international networking and institution-level guidelines (co-operation between various experts viz, institutions' Academic Boards, Deans, Heads of Faculty Departments, institutions' standing committees and the Students' Unions) (Anonymous, 2009). The success and/or failure of quality assurance is solely depended on the form of the procedures that are followed in the planning, implementation, evaluation, monitoring and development of education, training and teaching policies in the institutions. In Kenya, these procedures are normally done through an ISO certification system, which many institutions for higher education, training and learning are adopting as a yard stick towards quality assurance but in reality, it is not. An ISO certification system, which was initially meant for improving transparency and accountability in educational systems, providing exposure to methodologies of successful anti-corruption measures and initiating policy dialogue on anti-corruption 
in education sectors, is currently viewed as a uniform for institutions to hide either their corruption deals (in form of embezzlement, bribery, fraud, extortion and favouritism), nepotism, vague academic programmes or poor infrastructure for, what these institutions have declared and put on the paper is not what has been put in practice on the ground (Amundsen, 2000). Fraud in such academic institutions for higher education, training and learning is usually a serious threat to the integrity and reliability of ISO certification system, leading to the uncertainty as to the legitimacy of results, certificates issued and inkling about true face and performance of the institution in question (Hallak and Poisson, 2007). This misbehaviour in institutions for higher education, training and learning continue to happen under the watchdog of Commission for University Education, which has University Education Quality Assurance Unit that provides for external mechanism for monitoring and evaluating quality and relevance of education, training and learning for all universities in Kenya (this equally applies to both public and private universities). This mischief brings the institution into disrepute and greatly undermines the quality of graduates and it is not yet clearly known for how long it will be practiced.

However, according to UNICEF (2000), quality education and training comprises the following five well defined and assorted components:-

"Human Health: Learners who are socially, mentally and physically healthy, well-nourished and ready to actively participate and learn, and supported in education, training and learning by their families and communities;

Environmental Health: Environments that are healthy, safe, protective and gender-sensitive, and provide adequate resources and facilities for holistic education, training and learning;

Curriculum Content: Content that is reflected in relevant curricula and materials for the acquisition of basic skills, especially in the areas of literacy, numeracy and skills for life and knowledge in such areas as gender, health, political systems and governance, creativity and critical thinking skills, nutrition, HIV/AIDS prevention and sustainable management, peace and conflict resolution etc;

Delivery Processes: Processes through which professionally qualified trainers use learner-centred teaching approaches in well-managed lecture theatres and skilful assessment to facilitate learning and reduce disparities;

Outcomes: Outcomes that encompass knowledge, skills and attitudes, and are linked to national goals for education and positive participation in society."

In Kenya, these five levels of defining quality education and training are however, partially met. With the introduction of a fee-paying programme in university education system in 1992 as a government policy of cost-sharing*

\footnotetext{
* Cost-sharing in Kenyan higher education, training and learning was introduced in 1991 as a response to the ever-declining state budget, which did not keep pace with high student intake when the first cohort of the 8-4-4 system of students entered the university (Sanyal and Martin, 1998). Under this new
}

education costs at university level, a number of students from poor families rarely afford adequate food, clothing and general upkeep. It is indeed unfortunate that at times, contemporary student unrest has been attributed to poor diets in institutions (Ministry of Higher Education and Training, 2012). Students have the poorest medical cover and most of the health centres in their respective institutions for higher learning are poorly equipped and devastated and cannot therefore meet their anticipated health needs. In some constituent colleges and mushrooming village campuses, some of the staff serving students in these health centres are not professionally qualified with the required competences and experiences.

The environment in which education and training is conducted in some institutions for higher learning is in pathetic conditions, such that the weather is hostile, very poor infrastructure (including: - road and paths networks, internet facility etc), insufficient supply of water, pit latrines with nauseating smell, lack of sufficient office space for lecturers to operate from, lack of key social amenities and poor maintenance of those available, inadequate electricity etc. A number of offices in the various institutions for higher learning lack essential facilities. The geographical locations of some institutions is in such a way that you cannot work in the afternoon without a cooling fan, a fact dismissed by university administrators and managers who are out to please their immediate bosses and employers (University Councils and/or Board of Governors) at the expense of students' livelihoods. In the laboratories for these institutions, a number of them lack essential facilities and consumables in addition to professionally trained and experienced technologists who can competently and independently manage practical sessions for undergraduate and postgraduate students. Security of staff, students and equipments/facilities of institutions is not well guaranteed as lap tops and desk tops in the offices of lecturers and other staff members and laboratory equipments are mysteriously stolen without eminent explanation leading to their recovery. And in addition, incidences of commonly occurring cases of vandalism are on the rise in a number of institutions.

On many occasions, the recruitment and appointment procedures for staff members in institutions for higher learning are not competitive and transparent and hence, inefficient personnels are brought on board to serve the institutions. The issue of recruitment of quality staff members probably starts with the composition of the University Councils and/or Board of Governors, an issue that is politically instigated and determined instead of being academic.

policy, students and/or their parents were required to cover both modest tuition fees and contribute to the costs of maintenance. A student loan, bursary, scholarship and grants programme (from Higher Education Loans Board-HELB) was re-established in 1995 to enable the needy students to access higher education, training and learning following the failure of the initial programme, University Students Loans Schemes (USLS) due to its inability to recover loans. 
The Public University Inspection Board recommended that the recruitment of Deans, Directors of institutes/schools, heads of Departments, various administrators and managers for the operational units in universities be done competitively at all levels and remuneration be pegged to competence and performance of individuals in question (Kinyanjui, 2007) but this is not always the case as the final decision on who is who is made in restaurants when the person in question is present based on influence due to political affiliation, monetary resources, tribalism and/or nepotism (Kipkebut, 2010). This malpractice has witnessed a considerable number of young persons with fresh MSc/MA degree certificates from colleges and with no any experiences at all in any university education and training being appointed as academic leaders and heads of schools, departments, institutes and village campuses. This situation also applies to fresh $\mathrm{PhD}$ holders with no any experiences at all in any university education and training not to assume any position of academic leadership as in hierarchy levels of academia, these particular individuals are still being mentored under the supervision of senior lecturers and professors in whatever institution of establishment they are. It is indeed regrettable that this is the state of affairs in a considerable proportion of institutions for higher education, training and learning, particular in constituent colleges and mushrooming village campuses where this is being nurtured and described as quality alongside nepotism and tribalism. When institutions' recruited personnels are still learners, how do they advice institution management boards on the quality of services and personnels to recruit particularly senior lecturers and professors and their subsequent promotions through ranks? When institutions' recruited personnels are still learners, how do they determine the quality of running and management of academic programmes of institutions for higher education, training and learning, and advice accordingly? Under these circumstances therefore, it is perplexing and imprudent to expect the development and implementation of quality, focused, student-centred and job-market oriented academic programmes that are tandem with the needs of the rapidly evolving society and help promote the institutions. Secondly, the people being recruited by institutions and strategically positioned in academic leadership are at the optimal productive age with a sound mind of putting the institutions of higher education, training and learning on the international map if well nurtured. This is truly indirect brain "drain" and mismanagement of human resources for the African continent while maintaining the status quo for underdevelopment!

A number of institutions for higher education, training and learning are currently in the process of embracing modern technologies of delivery processes through which professionally qualified lecturers use student-centred training approaches in well-managed lecture theatres and skilful assessment to smooth the progress of training, learning and lessen discrepancy (UNICEF, 2000). The Information and
Communication Technologies (ICTs) has a far-reaching implication in driving world socio-economic and -cultural developments with a view to improving the well-being of humanity (Katitia, 2012). The ICTs are proving to offer veritable tool for ensuring success of the ongoing legal and regulatory reforms on institutions for higher education in Kenya with a view to improving the quality of teaching and learning (Bitner and Bitner, 2002; Tondeur et al., 2007). However, there are challenges that are affecting the efforts of the institutions of higher learning and Kenya Government to adopt ICTs in the education sector, namely, costs involved in the implementation process, internet access, professionally trained technical staff and adequate policy (Katitia, 2012). Luckily in Kenya, a National ICTs Policy was promulgated in January, 2006 with the objective of improving the livelihoods of people.

For a long period of time, institutions for higher education, training and learning in Kenya have been challenged to develop relevant academic programmes through which they will be able to produce relevant graduates with the knowledge, skills, techniques and attitudes and competences needed by the job market. This can be achieved by creating a link to connect education curriculum development and revision and the workforce industry. Secondly, making it mandatory that students undergoing training in institutions for higher learning must go for industrial internships to acquire necessary on-job training skills and competences before graduating as part and parcel of examinable course unit. By this strategy, it has been noted that the latest information, technology and practices are used when preparing students to become relevant in the society (Kadii Bin, 2012). In Kenya, however, very few academic programmes in institutions for higher education, training and learning involve and embrace industrial attachments as a course unit in their education, training and learning programmes.

\section{Conclusion}

There is growing responsiveness that recuperating education quality and relevance requires constellations of mutually reinforcing guiding principles at all levels of administration by government agencies in both public and private institutions for higher education, training and learning (Wilson, 2009) and focuses on the state of learners, learning environments, curriculum content, delivery process and outcomes. To facilitate the achievement of quality and relevant education, training and learning in respective institutions, however, a sustained visionary, effective, efficient, creative and sound academic leadership that recognizes values and ideas of professionally trained and quality personnels with ethical standards at all levels in the complex education system in the country is nevertheless critical. This can easily be realized, first, if politics and academic are separated, and each one of them is independently managed in its own domain (Amutabi, 2003; Ojiambo, 2009). 
Secondly, institution chiefs, administrators and managers must be truly academic leaders with exemplary and demonstratable track record in professional, private and public life, which do not have any links to corruption deals, tribalism, nepotism and favourism of any kinds (Chege, 2009; Kipkebut, 2010). The integrity of leaders of academic institutions must be that which is of a role model in the society (both at national and international levels). Thirdly, personnels in the mainstream of implementation of new reforms (particularly those pertaining to legal, economic, structural, university governance system and regulatory reforms) in the education, training and learning sectors and with respect to Universities Act, 2012, must ensure that there is a level playing field for both public and private universities as the Act stipulates without being biased in any ways. And fourthly, there is need for government commitment and political will on the national budgetary allocation of investment funds for the institutions for higher education, training and learning.

\section{A biodata}

Dr. Wycliffe Wanzala, PhD has been associated with university education, training, learning and research for over 18 years and is currently a research scientist and senior lecturer at the School of Pure and Applied Sciences, Department of Biological Sciences, South Eastern Kenya University in Kitui, Kenya. He holds a PhD in Resource Conservation and Production Ecology from Wageningen University and Research Centre, The Netherlands with a three-year laboratory and field research at the International Centre of Insect Physiology and Ecology (ICIPE) in Nairobi, Kenya. Currently, he is actively involved in the development of an educational institution in Bungoma County, Kenya and in research activities related to ethnoknowledge, ethnomedicines and biomedical sciences in Kenya.

\section{Acknowledgements}

This review article was written with the assistance of computer facilities jointly supported by the International Foundation for Sciences, Stockholm, Sweden and the Organization for the Prohibition of Chemical weapons, The Hague, The Netherlands through a grant AB/12782-2. The author wishes to acknowledge the time given by his institution, South Eastern Kenya University during the December, 2012 holidays, the time the first draft of the manuscript was written, revised and the final version of the manuscript completed during the Kenyan historic General Elections of Monday, March4th, 2013. I wish to thank The Catholic University of Eastern Africa (CUEA) most sincerely for allowing me to use its electronic and hard copy resources in the library to write and revise this manuscript. To Dr. Bethwel Onyango Owuor, many thanks for your kind assistance in printing for me the hard copy resources of literature at the Department of Natural Sciences, CUEA, while you were still the Head of the Department and to Prof. Dr. Richard Wolfgang Mukabana, thank you too for providing me with the office space to work from while in Nairobi town, Kenya.

\section{References}

[1] Amundsen, I. (2000). Corruption. Definition and concepts. Chr. Michelsen Institute (CMI). Development Studies and Human Rights, Bergen, Norway.

[2] Amutabi, N. M. (2003). Political interference in the running of education in post-independence Kenya: a critical retrospection. International Journal of Educational Development, 23: $141-144$

[3] Anami, L. (2013). President defends awarding of charters. The Standard Group Limited. http://www.standardmedia.co.ke/?articleID=2000077203\&st ory_title $=$ President-defends-awarding-of-charters., as retrieved on Sunday, February 24th, 2013; 6:00pm East African Time.

[4] Anonymous, (2009). University of Helsinki in brief: Evaluation of the quality of education: components of the quality of education. http://www.helsinki.fi/evaluation/quality_of_learning.html, as retrieved on Sunday, November 18th, 2012; 12:00 noon East African Time.

[5] Anonymous, (2012). Despite State efforts, bogus institutions continue to rise. Standard Digital, The Standard Group Limited

http://www.standardmedia.co.ke/?articleID=2000062110\&p ageNo=1., as retrieved on Sunday, February 24th, 2013; 5:11 pm East African Time.

[6] Anonymous, (2013). Service Charter. College of Education and External Studies, University of Nairobi, http://cees.uonbi.ac.ke/sites/default/files/cees/cees/CEESservice\%20charter_0.pdf., as retrieved on Wednesday February 26th, 2013; $2: 59$ pm East African Time.

[7] Bitner, N. and Bitner, J. (2002). Integrating Technology into the Classroom: Eight Keys to Success. Journal of Technology and Teacher Education, 10(1): 95-100.

[8] CHE and AfriQAN, (2012). Commission for Higher Education (CHE) and African Quality Assurance Network (AfriQAN). KenyaAfriQAN - INQAAHE Workshop on Good Practices Inequality Assurance. Proceedings of the workshop held at the Kenya School of Monetary Studies in Nairobi on 15th May, 2012, Nairobi, Kenya. http://www.che.or.ke/downloads/AfriQAN-

INQAAHE\%20Workshop.pdf., as retrieved on Sunday, November 18th, 2012; 08:29pm East African Time.

[9] Chege, A. M. (2009). Post-Moi era Discourse Patterns in Kenyan Universities: A Nation crying for Organic'Intellectuals. Kenya Studies Review, 1(1): 31-53.

[10] Fortunate, E. (2013). New law wants varsities to walk the quality talk. Daily Nation, Nation Media Group, A Media of Africa for Africa. http://www.nation.co.ke/Features/DN2/Dirty-survivaltactics-as-some-varsities-struggle/-/957860/1617234//12y3rxf/-/index.html., as retrieved on Monday, January 
21st 2013 at 02:00pm, East African Time.

[11] GoK, (2006). Government of Kenya (GoK). Constituency Development Fund. http://www.cdf.go.ke/index.htm as retrieved on October 23rd, 2006 at 3:47pm, East African Time.

[12] Hallak, J. and Poisson, M. (2007). Corrupt schools, corrupt universities: What can be done? International Institute for Educational Planning (IIEP-UNESCO). 7-9 rue Eugène Delacroix, 75116 Paris, France. Printed in IIEP's print shop, ISBN-10: 92-803-1296-0 (ISBN-13: 978-92-803-1296-6).

[13] Information Brochure, (2010/2011). The Centre for Open and Distance Learning (CODL), College of Education and External Studies. University of Nairobi. http://codl.uonbi.ac.ke/sites/default/files/cees/codl/codl bro chure.pdf., as retrieved on Wednesday February 26th, 2013; 3:39 pm East African Time.

[14] Kadii, Bin S. (2012). Analysts: Kenyan universities must align with job market demands. Sabahi, Covering the Horn of Africa. The English Version. $\mathrm{http} / /$ sabahionline.com/en_GB/articles/hoa/articles/features/ 2012/05/29/feature-02., as retrieved on Saturday, March 2nd, 2013; 7:56 pm East African Time.

[15] Katitia, M. D. (2012). The role of ICT integration into classroom in Kenya. A literature review. http://www.academia.edu/1410234/The_role_of_ICT_interg ration_into_classroom_in_Kenya._A_literature_review., as retrieved on Saturday, March 2nd, 2013; 6:45 pm East African Time.

[16] Khan, W. A. (2007). The Challenges of Distance Education. Online Journal of Space Communication. An International Electronic Journal, Issue 12: Challenges - UNESCO. $\mathrm{http}: / /$ spacejournal.ohio.edu/issue12/khan.html, as retrieved on Sunday, November 18th, 2012; 12:48 pm East African Time.

[17] Kiamba, C. (2004). Privately sponsored students and other income-generating activities at the University of Nairobi. Journal of Higher Education in Africa. 2 (2): 53-73.

[18] Kigotho, W. (2000). Arap Moi Sets up Private College. The Times Higher Education Supplement. March 31st, 2000. http://www.timeshighereducation.co.uk/story.asp?storyCode $=154796 \&$ sectioncode $=26$., as retrieved on Sunday, March 3rd, 2013; 2:40 pm East African Time.

[19] Kinyanjui, K. (2007). The transformation of higher education in Kenya: challenges and opportunities. Commission of Higher Education. Paper Presented at the Mijadala on Social Policy, Governance and Development in Kenya sponsored by Development Policy Management Forum on 9th July, 2007 at Nairobi Safari Club, Nairobi, Kenya. http://www.dpmf.org/images/12.pdf, as retrieved on Sunday, November 18th, 2012; 2:13 pm East African Time.

[20] Kipkebut, J. D. (2010). Organisational Commitment and Job satisfaction in higher educational institutions: the Kenyan case. Doctor of Philosophy Thesis, Middlesex University, Business School, Lodon, UK.

[21] Lime, A., Obara, V., Marete, G., Ngeta, E., Wanjiru, E., Njagi, J. and Kanyi, J. (2011). Bogus colleges shut down in crackdown. Nation Media Group, Daily Nation Newspaper, Nairobi, Kenya. http://www.nation.co.ke/News/Boguscolleges-shut-down-in-crackdown-/-/1056/1091936//rk04akz/-/index.html., as retrieved on Tuesday, January 18th, 2011 at 21:00, East African Time.

[22] Mengo, B. (2011). Challenges bedevil Kenya's university education. Xinhua News Agency, China, Xinhuanet, English http://news.xinhuanet.com/english2010/indepth/201111/14/c 131246290.htm., as retrieved on Saturday, February23rd, 2013; 10:11 am East Africa Time.

[23] Ministry of education, (2012). Task force on the realignment of the education sector to the constitution of Kenya, 2010. Towards a globally competitive quality education for sustainable development. Report of the task force, February, 2012.

[24] Ministry of Higher Education and Training, (2012). Report on the ministerial committee for the review of the provision of student housing at South African universities. Department of Higher Education and Training, Pretoria, South Africa. ISBN: $\quad 978-0-621-40731-0$ (RP83/2012). http://www.dhet.gov.za/LinkClick.aspx?fileticket=4VNwYJ $\% 2 \mathrm{BEwvA} \% 3 \mathrm{D} \&$ tabid $=92 \& \mathrm{mid}=495$., as retrieved on Saturday, March 2nd, 2013; 10:25 am East African Time.

[25] Mogambi, H. (2013). Stop turning polytechnics into varsities. Nation Media Group, Daily Nation Newspaper, Nairobi, Kenya. $\quad$ http://www.nation.co.ke/oped/Opinion//440808/1674446/-/kkqflez/-/index.html., as retrieved on Friday, January 25th, 2013; 4:16 pm East African Time.

[26] Muhirwa, J-M. (2009). Teaching and Learning Against all Odds: A Video-Based Study of Learner-to-Instructor Interaction in International Distance Education. The international review of research in open and distance learning, 10 (4).

http://www.irrodl.org/index.php/irrodl/article/view/628/131 4., as retrieved on Sunday, February24th, 2013; 2:57 pm, East African Time.

[27] Mwangi, W. S. (2012). Beyond Quantity: Higher Education in Kenya. http://web.univpau.fr/RECHERCHE/CREPAO/pdf/kampala_mwangi.pdf, as retrieved on Sunday, November 18th, $2012 ; 11: 03 \mathrm{pm}$ East African Time.

[28] Ndanyi, M. (2010). 100 illegal colleges in Eldoret to be closed. Mars Group Kenya. http://www.marsgroupkenya.org/multimedia/?StoryID=3028 69, as retrieved on Saturday, March 2nd, 2013; 10:16 pm East African Time.

[29] Nganga, G. (2010a). KENYA: Major plan to improve training institutions. University World News or Higher Education Web Publishing, Africa Edition, July 18th 2010, Issue No: 58. http://www.universityworldnews.com/article.php?story=201 00716194758897., as retrieved on Saturday, February 23rd, 2013; 12:00pm, East Africa Time.

[30] Nganga, G. (2010b). KENYA: Government set to close unregistered colleges. University World News or Higher Education Web Publishing Africa Edition, September 19th, 2010, Issue $\quad$ No: 62. http://www.universityworldnews.com/article.php?story=201 $0091807573177 \&$ mode=print., as retrieved on Saturday, February 23rd, 2013; 12:31 pm, East Africa Time.

[31] Ngolovoi, M. (2006). Means testing of student loans in Kenya. Presented at the Comparative and International Higher Education Policy: Issues and Analysis Workshop: 
University at Albany.

[32] Ngolovoi, M. (2009). Country profile: Higher Education: Kenya.

http://gse.buffalo.edu/org/inthigheredfinance/files/Country_ Profiles/Africa/Kenya.pdf., as retrieved on Sunday, November 18th, 2012; 1:33 pm East African Time.

[33] Ngure, K. P. (2012). Dirty survival tactics as some varsities struggle. Daily Nation, Nation Media Group, A Media of Africa for http://www.nation.co.ke/Features/DN2/Dirty-survivaltactics-as-some-varsities-struggle/-/957860/1617234//12y3rxf/-/index.html., as retrieved on Monday, 12th November, 2012; 4:30pm East African Time.

[34] Ojiambo, P. O. (2009). Quality of Education and its Role in National Development: A Case study of Kenya's Educational Reforms. Kenya Studies Review, 1(1): 133-149.

[35] Otieno, W. (2004). Student Loans in Kenya: Past Experiences, Current Hurdles, and Opportunities for the Future. Journal of Higher Education in Africa, 2(2): 75-99.

[36] Otieno, W. (2009). Kenya: Brief Description of the Higher Education System in Kenya. http:/gse.buffalo.edu/org/inthigheredfinance/files/Country_ Profiles/Africa/Kenya.pdf., as retrieved on Sunday, February 24th, 2013; 11:48pm, East African Time.

[37] Sanyal , B. and Martin M. (1998). Management of Higher Education with Special Reference to Financial Management in African Countries. The International Institute for Educational Planning (IIEP-UNESCO), Paris, France.

[38] Tairo, M. (2006). The State of Higher Education in Kenya. a TakingITGlobal online publication. Education, Global Education, Panorama. http://www.tigweb.org/youthmedia/panorama/article.html?ContentID $=7023 \&$ start $=5271$., as retrieved on Sunday, February 24th, 2013; 10:38pm, East African Time.

[39] The Center for Public Education, (2005). Teacher quality and student achievement: Research review. http://www.centerforpubliceducation.org/Main-

Menu/Staffingstudents/Teacher-quality-and-studentachievement-At-a-glance/Teacher-quality-and-studentachievement-Research-review.html, as retrieved on Sunday, November 18th, 2012; 2:13 pm East African Time.
[40] The Standard Group Limited, (2009). Move to abolish parallel degree programmes in Kenyan universities. The Standard Team, Nairobi, Kenya, Monday, March 30, 2009. http://africanewsonline.blogspot.com/2009/03/move-toabolish-parallel-degree.html., as retrieved on Wednesday 26th, 2013; 6:00 pm East African Time.

[41] Tondeur, J., Van Braak, J. and Valcke, M. (2007). Curricula and the use of ICT in education: Two worlds apart? Curricula and the use of ICT in education. British Journal of Educational Technology, 38(6): 962-976.

[42] UNICEF, (2000). Defining Quality in Education. The United Nations Children's Fund (UNICEF). A publication of UNICEF. Programme Division Education. Document No. $\mathrm{UNICEF} / \mathrm{PD} / \mathrm{ED} / 00 / 02$. The principal researcher for this paper was Jeanette Colby, Miske Witt and Associates, for the Education Section, Programme Division, UNICEF New York, USA.

[43] Wachira, G. (2013). Quality higher education holds key to economic growth. Business Daily Africa, Daily Nation, Nation Media Group, A media of Africa for Africa. http://www.businessdailyafrica.com/Opinion-andAnalysis/Quality-higher-education-holds-key-to-economicgrowth/-/539548/1698700/-/69nwl9/-/index.html., as retrieved on Tuesday, February 19th, 2013 at 11:35am, East Africa Time.

[44] Wainaina, M. (2011). Influence of gender roles on students pursuing module ii programs in Kenyan public universities. International Journal of Humanities and Social Science. Vol. 1 No. 13, [Special Issue - September 2011] 115. http://www.ijhssnet.com/journals/Vol_1_No_13_Special_Iss ue_September_2011/15.pdf., as retrieved on Monday, February 25 th, 2013; 3:28 pm, East Africa Time.

[45] Wanjohi, A. M. (2011). Development of Education System in Kenya since Independence. KENPRO Online Papers Portal. Available online at www.kenpro.org/papers., as retrieved on Sunday, November 18th, 2012; 5:01 pm East African Time.

[46] Wilson, S. (2009). Teacher Quality. Education Policy White Paper. National Academy of Education Working Group on Teacher Quality. http://naeducation.org/Teacher_Quality_White_Paper.pdf., as retrieved on Sunday, November 18th, 2012; 4:51 pm East African Time. 